\title{
Aqueous phase epoxidation of 1-butene catalyzed by suspension of $\mathrm{Au} / \mathrm{TiO}_{2}+\mathrm{TS}-1$
}

\author{
Jian Jiang ${ }^{1}$, Harold H. Kung ${ }^{2 \star}$, Mayfair C. Kung ${ }^{2 \star}$, Jiantai Ma ${ }^{3}$ \\ www.goldbulletin.org
}

\begin{abstract}
A combination of two catalysts, $\mathrm{Au} / \mathrm{TiO}_{2}$ and TS-1 were used to catalyze the demanding reaction of butene epoxidation in an aqueous solution using molecular oxygen under very mild reaction conditions. Peroxy initiator was not necessary but carbon monoxide as a sacrificial reductant was needed. Carbon monoxide conversions increase with time on stream suggesting the generation of a highly active aqueous phase $\mathrm{CO}$ oxidation catalyst.
\end{abstract}

\section{Introduction}

Since the discovery by the group of Haruta [1] that supported Au catalysts have exceptional CO oxidation activities, these catalysts have been investigated extensively for many interesting gas phase reactions. Reviews on CO oxidation [2], WGS [3], hydrochlorination and hydrogenation [4] have been published. Recently, interesting oxidation reactions catalyzed by supported Au catalysts in the liquid phase have also attracted significant attention. Noteworthy examples include the selective oxidation of alkene [5], alcohol and glucose [6], and the formation of hydrogen peroxide from $\mathrm{H}_{2}$ and $\mathrm{O}_{2}$ [7]. In this article we examine two low temperature aqueous phase oxidation reactions, CO oxidation and alkene epoxidation, using a binary catalytic system of a physical mixture of $\mathrm{Au} / \mathrm{TiO}_{2}$ and TS-1.

There has been limited success in the epoxidation of unactivated alkenes with molecular oxygen because it is such a demanding reaction. The only known commercial processes are the Ag catalyzed epoxidation of ethylene [8] and butadiene [9]. These catalytic processes however fail when the alkene possesses allylic hydrogen. Recently, there has been extensive exploration using supported Au catalyst for alkene epoxidation with molecular $\mathrm{O}_{2}$. These studies fall into three classes, those with molecular $\mathrm{O}_{2}$ alone, those with the addition of a peroxy initiator, and those that require a sacrificial reductant. Very low turnovers of propene epoxidation were observed using $\mathrm{H}_{2} \mathrm{O}, \mathrm{O}_{2}, \mathrm{C}_{3} \mathrm{H}_{6}$ over $\mathrm{Au} / \mathrm{TiO} \mathrm{O}_{2}$ catalysts [10]. Turner et. al. [11] reported oxidation of styrene to benzaldehyde, styrene epoxide and acetopheneone over $\mathrm{Au}_{55}$ clusters. However, the activity and the selectivity to epoxide were low. The addition of a peroxy initiator accelerated epoxidation reactions [5], but the product distribution appeared to be very solvent dependent. The most intensely studied system is one when $\mathrm{H}_{2}$ was included as a sacrificial reductant, and the catalysts used were $\mathrm{Au} / \mathrm{TiO}_{2}$ [12], Au/TS-1 and Au/MCM-41 [13] and Au-Ba/Ti-TUD 
[14]. The proposed mechanism for these catalysts involves the formation of $\mathrm{H}_{2} \mathrm{O}_{2}$ on the Au active site and the migration of the peroxide onto neighboring $\mathrm{Ti}$ to form $\mathrm{Ti}$ hydroperoxy species which can donate an [O] atom to propylene to form propylene epoxide [14].

The epoxidation of $\mathrm{C}_{3} \mathrm{H}_{6}$ in the presence of $\mathrm{H}_{2}$ and $\mathrm{O}_{2}$ was conducted in the gas phase at moderately high temperature. Interestingly, the group of Robert J. Davis [15] reported in 2007 that $\mathrm{Au} / \mathrm{TiO}_{2}$ and $\mathrm{Au} / \mathrm{C}$ were able to catalyze the formation of $\mathrm{H}_{2} \mathrm{O}_{2}$ in the aqueous phase at ambient temperature, using $\mathrm{CO}$ as a sacrificial reductant (Eq. 1)

$$
\mathrm{CO}+\mathrm{O}_{2}+\mathrm{H}_{2} \mathrm{O} \rightarrow \mathrm{CO}_{2}+\mathrm{H}_{2} \mathrm{O}_{2}
$$

This low temperature method to generate $\mathrm{H}_{2} \mathrm{O}_{2}$ may be safer than by $\mathrm{H}_{2}$ oxidation at higher temperatures, and capturing this $\mathrm{H}_{2} \mathrm{O}_{2}$ for alkene epoxidation appears to be a very fruitful area of investigation. TS-1 is known to be an excellent catalyst for alkene epoxidation using $\mathrm{H}_{2} \mathrm{O}_{2}$ as the oxidant [16].

Figure 1: Schematic of reactor set up

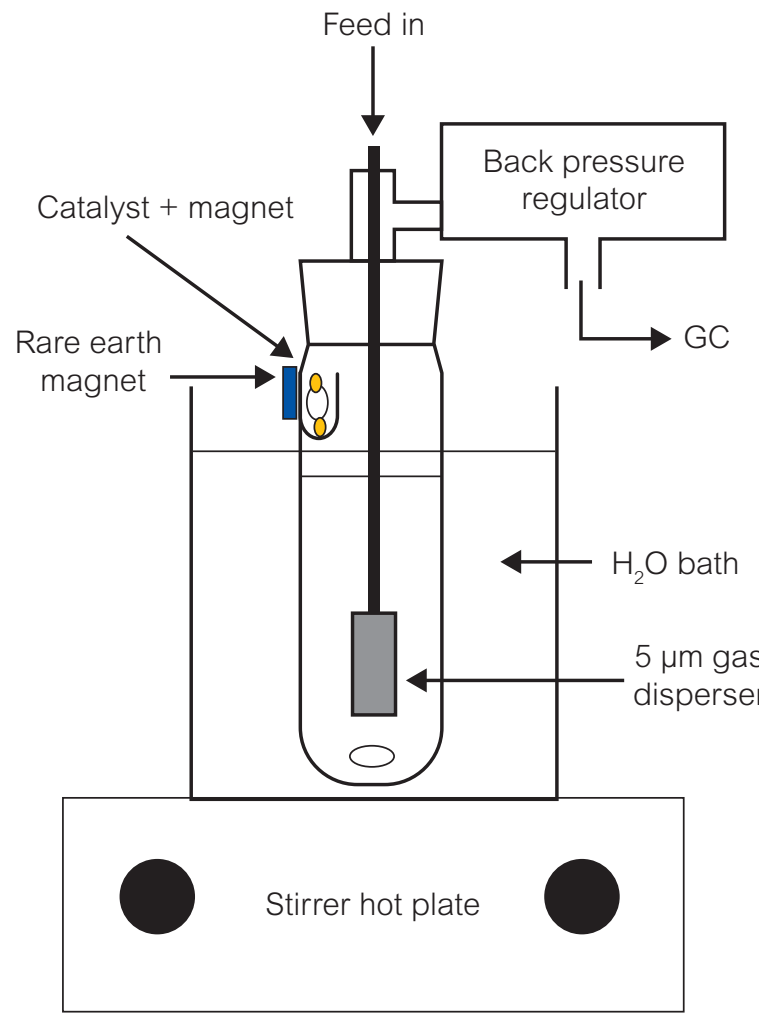

A combination of $\mathrm{Au} / \mathrm{TiO}_{2}$ and TS-1 was then chosen for $\mathrm{CO}$ assisted butene epoxidation study. The effect of butene and TS-1 on CO oxidation was also investigated during the epoxidation reaction.

\section{Methods}

The two different batches of $\mathrm{Au} / \mathrm{TiO} 2$ catalysts used in the reaction (no observable difference in the catalytic performance) were supplied by World Gold Council. The Au loadings of $\mathrm{Au} / \mathrm{TiO}_{2}-02-4$ and $\mathrm{Au}-\mathrm{TiO}_{2}-02-9$ were 1.51 and 1.49 wt. $\%$ and the average Au particle sizes were $3.8 \pm 1.5 \mathrm{~nm}$ and $3.6 \pm 1.32 \mathrm{~nm}$, respectively. TS-1 was synthesized using the method of Thangaraj et al. [17]. Diffuse reflectance UV visible spectroscopy (Perkin Elmer LAMBDA 1050) was used to verify the absence of extra framework Ti. The silicalite sample was synthesized using the same procedure as for TS-1, except that TiBuOH was omitted.

The epoxidation reaction was carried out in a high pressure glass reactor (Cole-Palmer) which contained $50 \mathrm{~mL}$ of ion-exchanged distilled water (DDI $\mathrm{H}_{2} \mathrm{O}, \mathrm{pH}$ 5.5). The reactor was maintained at $40^{\circ} \mathrm{C}$ (except when specified). The gas feed composition, $2.5 \% \mathrm{CO}, 1.25 \% \mathrm{O}_{2}$ and $1.25 \%$ 1-butene, balance He, was adjusted using 5850E

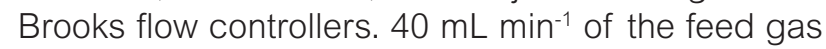
was directed into the aqueous phase through a $5 \mu \mathrm{m}$ stainless steel porous frit (Scientific Instrument Services). The pressure in the vessel was maintained at $480 \mathrm{kPa}$ with a back pressure regulator (Mighty Mite). The experiments were started usually with the catalysts $\left(0.1 \mathrm{~g} \mathrm{Au} / \mathrm{TiO}_{2} \pm 0.15 \mathrm{~g} \mathrm{TS}-1\right)$ placed above the water level in a small polyethylene cup with a small magnet in the cup and held in place by a rare earth magnet placed outside the reactor (Fig1). At a predetermined time (defined as time $=0$ ), the rare earth magnetic, external to the reactor, was used to guide the cup of catalyst inside the reactor into the water, thereby initiating the aqueous phase catalytic reaction. After the reaction, $50 \mathrm{~mL}$ of $\mathrm{H}_{2} \mathrm{O}$ was used to replace the $\mathrm{H}_{2} \mathrm{O}$-catalysts mixture and the feed was again introduced at $480 \mathrm{kPa}$ to calibrate the GC peak areas so as to quantify the gas composition accurately. The exit gas from the reactor was monitored with GC. All liquid products were separated from the solid catalysts by filtration through a $0.2 \mu \mathrm{m}$ PVDF membrane (Pall) and analyzed with an Agilent 6890 GC. The GC columns were Alltech carbosphere packed column for $\mathrm{CO}, \mathrm{O}_{2}$ and $\mathrm{CO}_{2}$ and Alltech EC-wax capillary column (0.32 $\mathrm{mm} * 30 \mathrm{~m}$ ) for organics. 
$\mathrm{H}_{2} \mathrm{O}_{2}$ was titrated by ceric sulfate using a Ferroin indicator. The indicator solution was prepared by dissolving $0.123 \mathrm{~g}$ iron (II) sulfate heptahydrate $\left(\mathrm{FeSO}_{4} \cdot 7 \mathrm{H}_{2} \mathrm{O}\right)$ into $15 \mathrm{~mL}$ DDI water, then adding $0.259 \mathrm{~g} \mathrm{1,10-phenanthroline.} \mathrm{The} \mathrm{titration} \mathrm{solution,}$ $0.6875 \mathrm{mM} \mathrm{Ce}\left(\mathrm{SO}_{4}\right)_{2}$, was prepared by dissolving $0.114 \mathrm{~g}$ cerium(IV) sulfate $\left(\mathrm{Ce}\left(\mathrm{SO}_{4}\right)_{2}\right)$ into dilute sulfuric acid $(1 / 19 \mathrm{v} / \mathrm{v})$. Two drops of indicator was added to a solution prepared by mixing $5 \mathrm{~mL}$ of sample and $10 \mathrm{~mL}$ diluted sulfuric acid (1/19 v/v). Then ceric sulfate solution was added dropwise to the sample solution until the color changed.

Due to the high solubility of $\mathrm{CO}_{2}$ in water and the continuing changes in $\mathrm{CO}$ conversions with time on stream, it is difficult to obtain good carbon balance and assess the importance of the combustion pathway. This value, can however, be assessed by summing $\mathrm{O}_{x \mathrm{~s}}$ (defined as the $\mathrm{O}$ beyond what is required for stoichiometric $\mathrm{CO}$ oxidation) over the period of the experiment and comparing it with the total alkene reacted or epoxide formed. $\mathrm{O}_{\mathrm{xs}}$ can be caluclated from $\mathrm{R}_{\mathrm{Oxs}}$ which is the difference in the rates of oxygen atom and $\mathrm{CO}$ consumption (Eq. 2)

$$
\mathrm{R}_{\text {Oxs }}=2^{*} \mathrm{R}_{\mathrm{O} 2 \text { used- }} \mathrm{R}_{\text {co used }}
$$

The efficiency in $\mathrm{O}_{\mathrm{xs}}$ production, $\mathrm{E}_{\mathrm{Oxs}}$, is defined as the ratio of $\mathrm{O}$ consumed for oxidation other than the production of $\mathrm{CO}_{2}$ to $\mathrm{CO}$ consumed.

$$
\mathrm{E}_{\mathrm{Oxs}}=\mathrm{R}_{\mathrm{Oxs}} / \mathrm{R}_{\mathrm{co}}=\text { efficiency in } \mathrm{O}_{\mathrm{xs}} \text { production }
$$

\section{Results}

\section{3 a. $\mathrm{Au} / \mathrm{TiO}_{2}$}

Figure 2a shows $\mathrm{CO}$ oxidation over a $\mathrm{Au} / \mathrm{TiO}_{2}$ catalyst at room temperature in a feed of $2.5 \% \mathrm{CO}$ and $1.25 \%$ $\mathrm{O}_{2}$ in $\mathrm{He}$. Before $\mathrm{t}=0$, the catalyst was suspended above the liquid and was relatively active for $\mathrm{CO}$ oxidation, albeit the activity was noticeably lower than when the same catalyst was placed in a plug flow reactor. At $t=0$, the catalyst was dispersed into the aqueous phase and the $\mathrm{CO}$ conversion decreased sharply due to the low solubility of the gases in $\mathrm{H}_{2} \mathrm{O}$. $\mathrm{E}_{\text {Oxs }}$ was zero in the gas phase but increased transiently to a value of $\sim 0.3$ before decaying to zero after around 100 min. When the experiment was repeated with half the amount of catalyst, the aqueous phase $\mathrm{CO}$ conversions and $\mathrm{E}_{\text {Oxs }}$ did not change significantly, suggesting that the rate limiting factor was not the amount of catalyst but the dissolution of gases. At the end of the experiment, with $0.05 \mathrm{~g} \mathrm{Au} / \mathrm{TiO}_{2}$ catalyst, there were $5.2 \mu$ moles of $\mathrm{H}_{2} \mathrm{O}_{2}$ in the aqueous phase. This amount was less than the estimate of Oxs consumed, which could be due to handling loss and continual decomposition of $\mathrm{H}_{2} \mathrm{O}_{2}$ before titration. However the amount of $\mathrm{H}_{2} \mathrm{O}_{2}$ detected exceeded the amount expected from the equilibrium concentration of the oxidation of $\mathrm{H}_{2} \mathrm{O}$ with $\mathrm{O}_{2}$ by many orders of magnitude $\left(\mathrm{K}_{25}=.2 .58^{*} 10^{-22}\right.$ for $\mathrm{H}_{2} \mathrm{O}$ oxidation with $\mathrm{O}_{2}$ ).

Figure $3 a$ shows that when the $\mathrm{H}_{2} \mathrm{O}$ temperature was increased to $40^{\circ} \mathrm{C}$, CO conversions in the gas phase (gas phase temperature was less than $40^{\circ} \mathrm{C}$ ) and aqueous phase increased slightly. When $1.25 \%$ 1-butene was included in the feed, CO conversion

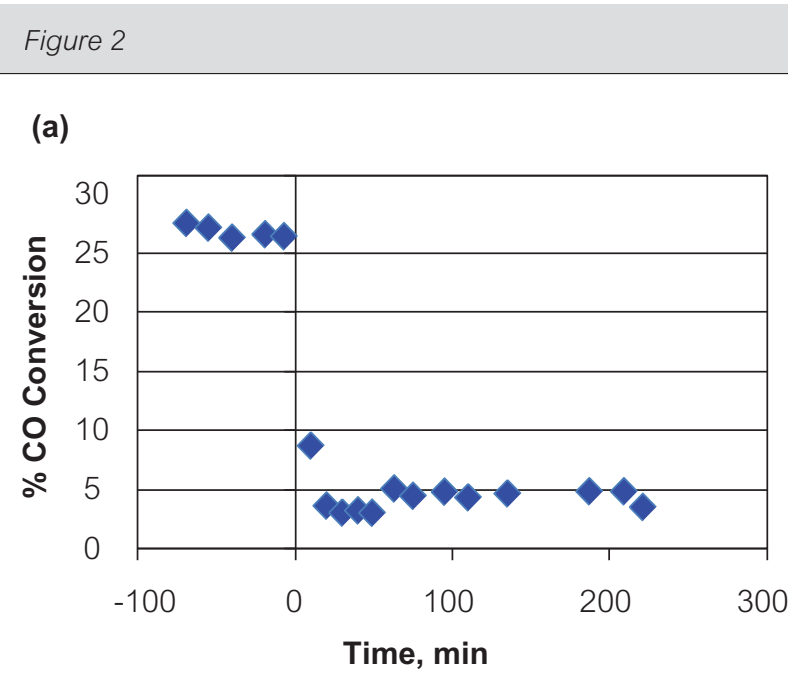

(b)

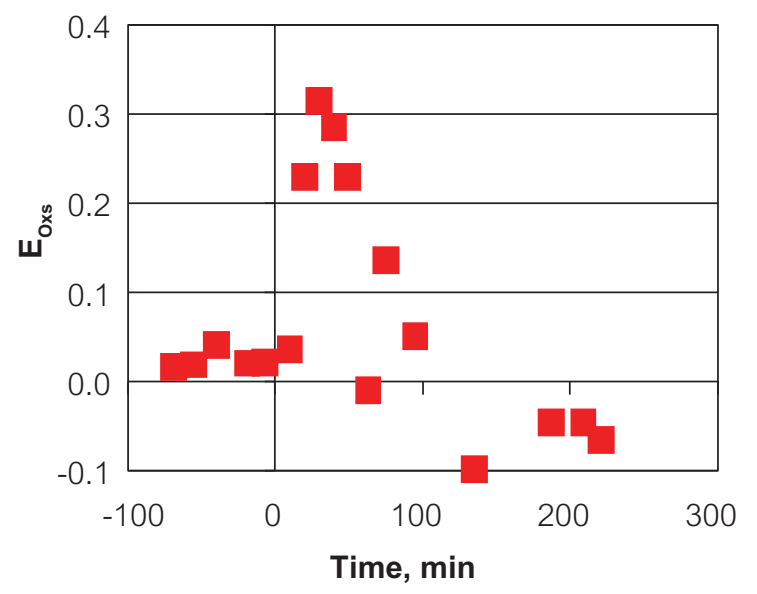

$\%$ CO conversion and efficiency in $O_{x S}$ production $\left(E_{O x s}\right)$, as a function of time. Reaction condition: $2.5 \% \mathrm{CO}, 1.25 \% \mathrm{O}_{2}$ and balance $\mathrm{He}$, over $\mathrm{Au} / \mathrm{TiO}_{2}$ catalyst at $25^{\circ} \mathrm{C}$ 


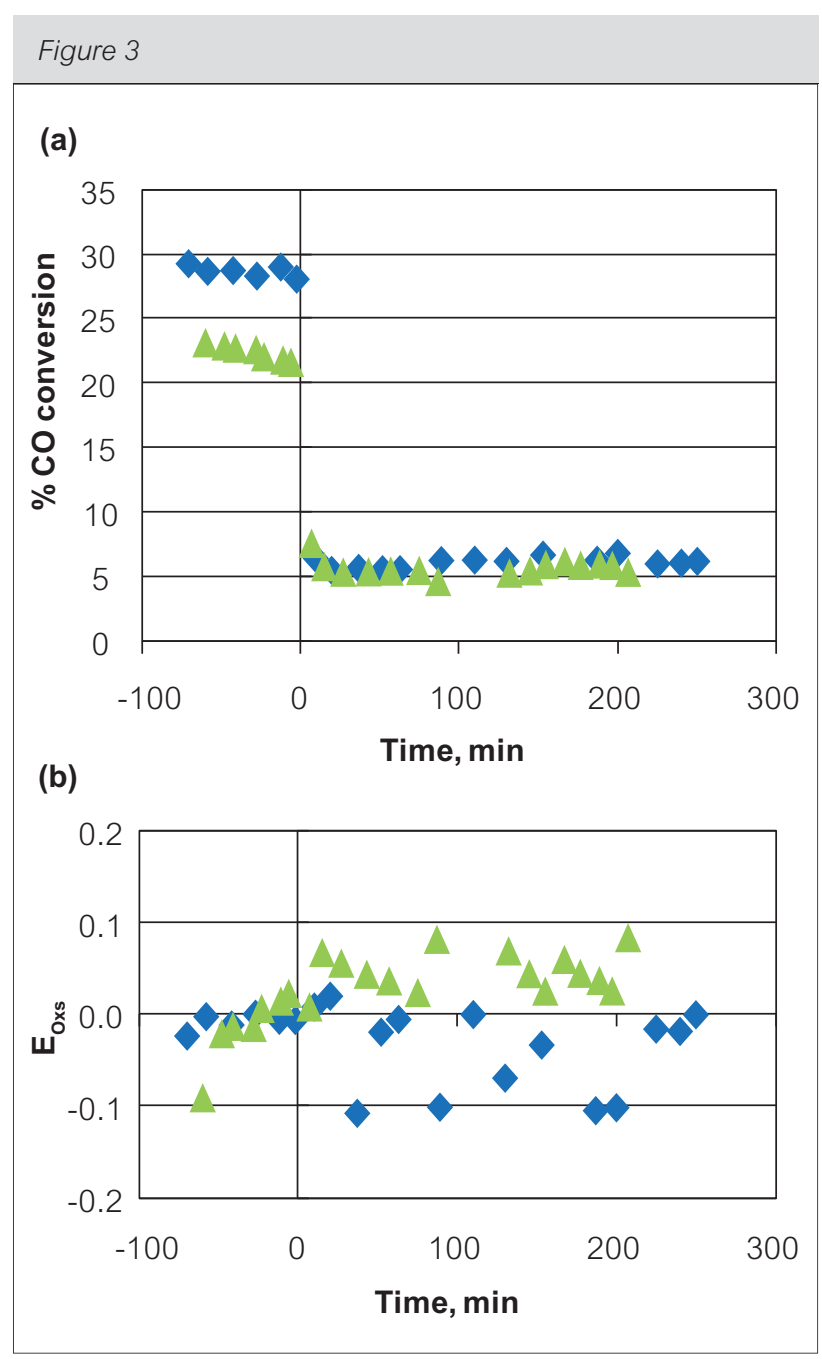

(a) \% CO conversions and (b) $\mathrm{E}_{\text {oxs }}$ over $\mathrm{Au} / \mathrm{TiO} \mathrm{O}_{2}$ catalyst at $40^{\circ} \mathrm{C}$. $\checkmark$ : feed contains $2.5 \% \mathrm{CO}$ and $1.25 \% \mathrm{O}_{2}$ in $\mathrm{He} ; \Delta$ : feed contains $2.5 \% \mathrm{CO}, 1.25 \% \mathrm{O}_{2}$ and $1.25 \% \mathrm{C}_{4} \mathrm{H}_{8}$ in $\mathrm{He}$

was slightly suppressed in the gas phase but remained unaffected in the aqueous phase. The $\mathrm{E}_{\mathrm{Oxs}}$ was close to zero, with and without butene in the feed, and was much less than that observed under room temperature reaction condition (Fig. 3b).

\section{3b. $\mathrm{Au} / \mathrm{TiO}_{2}+\mathrm{TS}-1$ catalyst activity}

Figure $4 a$ shows the $\mathrm{CO}$ and $\mathrm{O}_{2}$ conversions for three separate runs in a feed of $\mathrm{CO}, \mathrm{O}_{2}$ and 1butene using the binary catalyst system of $\mathrm{Au} / \mathrm{TiO}_{2}$ + TS-1. CO conversion in the gas phase was lower than the runs without TS-1 because diffusional effect was more severe in a deeper bed in the polyethylene cup due to the presence of TS-1. In the gas phase, within uncertainties, the $\mathrm{O}_{2}$ and $\mathrm{CO}$ conversions were identical. Once the catalysts were dispersed into the aqueous phase, $\mathrm{O}_{2}$ conversions were always

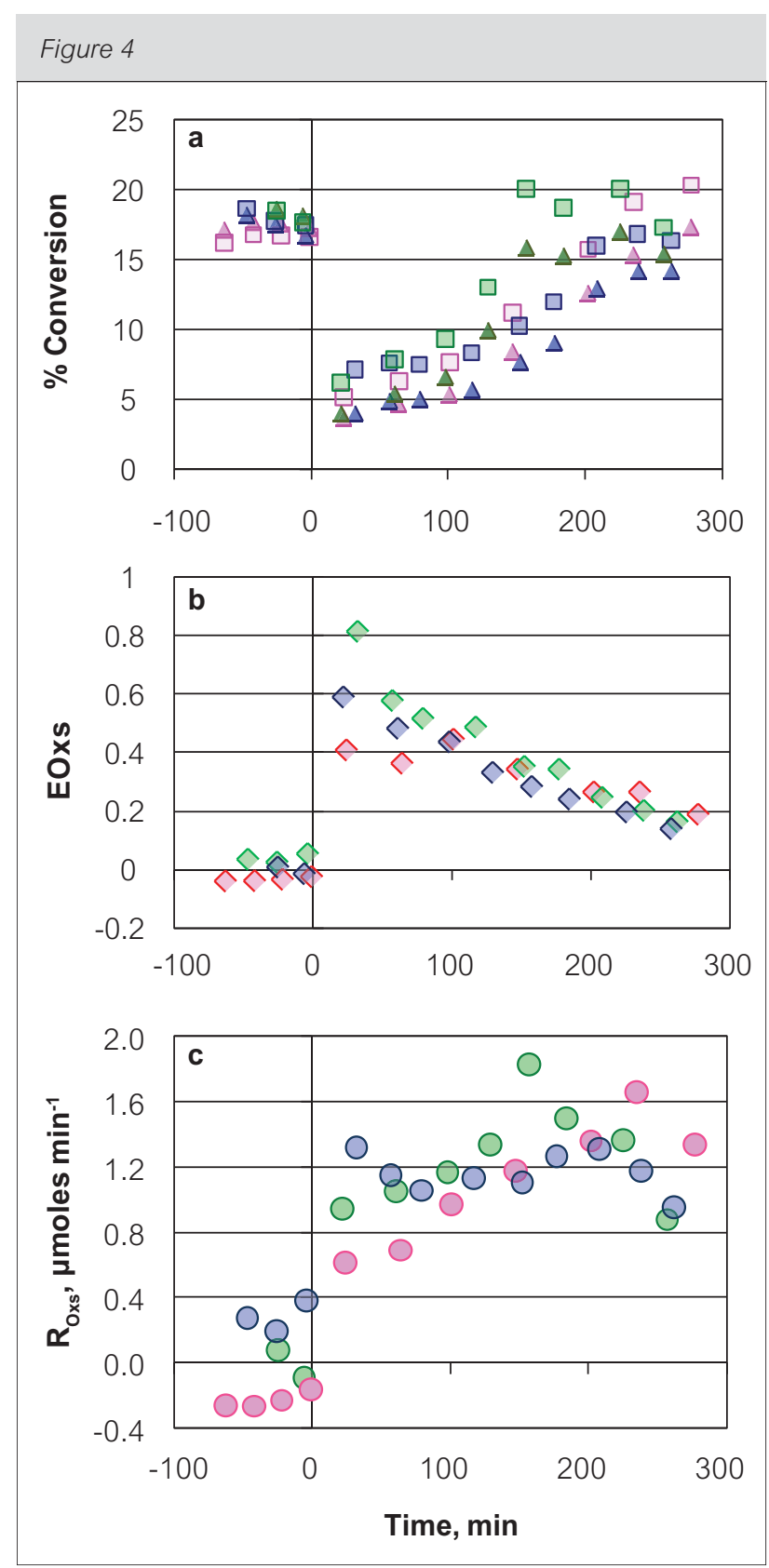

(a) \% $\mathrm{CO}$ and $\mathrm{O}_{2}$ conversions, (b) $E_{\text {oxs }}$ and (c) ROxs over Aul $\mathrm{TiO}_{2}+\mathrm{TS}-1$ binary catalytic system at $40^{\circ} \mathrm{C}$. Feed composition: $2.5 \% \mathrm{CO}, 1.25 \% \mathrm{O}_{2}, 1.25 \%$ butene, balance He. $\square: \mathrm{O}_{2}$ conversion, $\Delta$ : CO conversion; $\diamond: E_{\text {Oxs }}, O: R_{O x s}$. Each color set for 4(a), (b) and (c) corresponds to the same run

higher than the corresponding $\mathrm{CO}$ conversions. Both $\mathrm{CO}$ and $\mathrm{O}_{2}$ conversions increased with time on stream until at the end of the experiment their conversions were similar or higher than that of the initial gas phase conversions. However, there was no parallel increase in the rate of $\mathrm{O}_{\mathrm{xs}}$ production (Fig. 4c). 


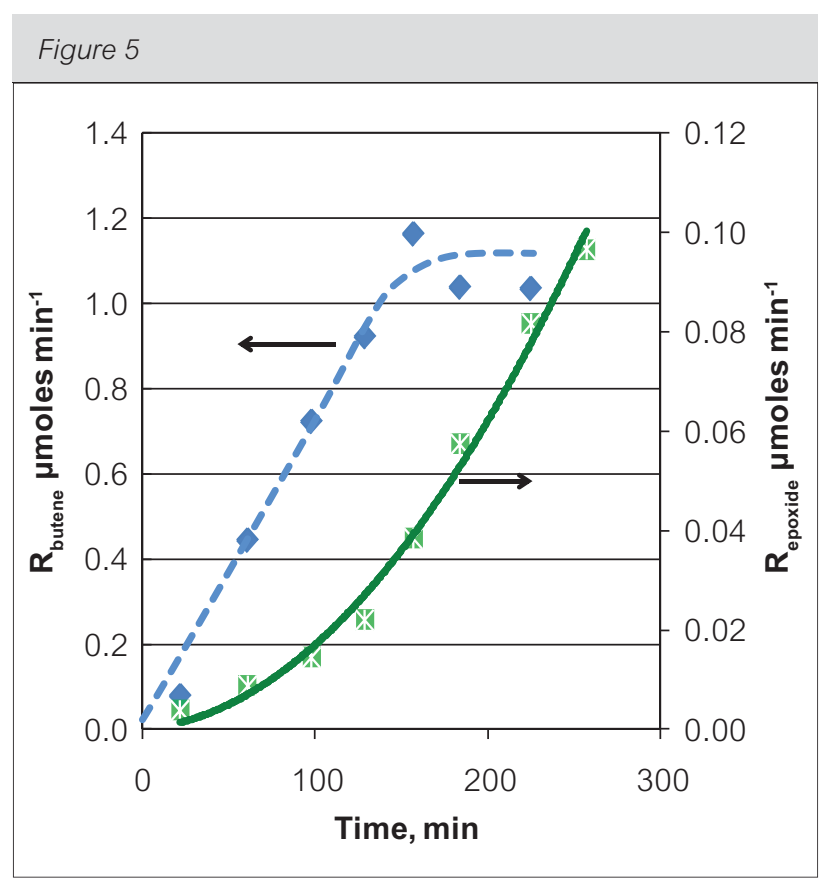

Rates of butene consumption and butene 1,2-epoxide formation as observed in the gas phase. Reaction conditions same as Figure 4

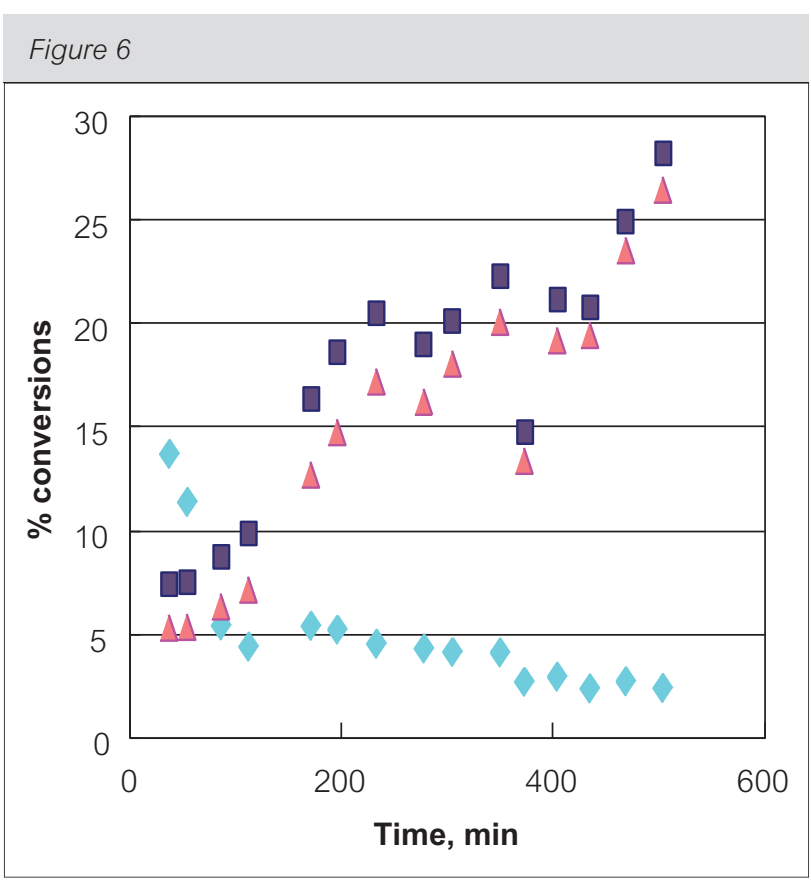

Conversions as a function with time on stream over Au/TiO + TS-1 in the aqueous phase at $40^{\circ} \mathrm{C}$. Feed composition same as Figure 4. $\square \mathrm{O}_{2}, \Delta \mathrm{CO}, \diamond 1$-butene.

Table 1: Products distribution in $\mathrm{CO}$ assisted 1-butene epoxidation in the aqueous phase at $40^{\circ} \mathrm{C}$

\begin{tabular}{|c|c|c|c|c|c|c|c|}
\hline \multirow[b]{2}{*}{ Run \# } & \multirow[b]{2}{*}{ Catalyst } & \multirow[b]{2}{*}{ Feed } & \multicolumn{5}{|c|}{ Quantity, $\times 10^{-5}$ moles } \\
\hline & & & $\begin{array}{l}\text { Total Epoxide } \\
\text { (gas/liquid) }\end{array}$ & Diol & $O_{x s}$ & $\begin{array}{l}\text { Butene } \\
\text { consumed }\end{array}$ & $\mathrm{H}_{2} \mathrm{O}_{2}{ }^{b}$ \\
\hline 1 & $\mathrm{Au} / \mathrm{TiO}_{2}+\mathrm{TS}-1$ & $\mathrm{CO}+\mathrm{O}_{2}+\mathrm{C}_{4} \mathrm{H}_{8}$ & $3.0(0.8 / 2.2)$ & 15 & 31 & 19 & 0.4 \\
\hline 2 & $\mathrm{Au} / \mathrm{TiO}_{2}+\mathrm{TS}-1$ & $\mathrm{CO}+\mathrm{O}_{2}^{2}+\mathrm{C}_{4}^{4} \mathrm{H}_{8}^{8}$ & $2.0(0.6 / 1.4)$ & 14 & 30 & 29 & 0.3 \\
\hline 3 & $\mathrm{Au} / \mathrm{TiO}_{2}^{2}+\mathrm{TS}-1$ & $\mathrm{CO}+\mathrm{O}_{2}^{2}+\mathrm{C}_{4}^{4} \mathrm{H}_{8}^{8}$ & $3.6(0.7 / 2.9)$ & 18 & 30 & 26 & 0.6 \\
\hline 4 & $\mathrm{Au} / \mathrm{TiO}_{2}^{2}+\mathrm{TS}-1$ & $\mathrm{O}_{2}+\mathrm{C}_{4} \mathrm{H}_{8}{ }^{8}$ & 0 & 0 & 0 & 0 & 0 \\
\hline 5 & $\mathrm{Au} / \mathrm{TiO}_{2}+\mathrm{TS}-1$ & $\mathrm{CO}+\mathrm{O}_{2}$ & $N D^{a}$ & ND & $\sim 6$ & ND & ND \\
\hline 6 & TS-1 & $\mathrm{CO}_{2}+\mathrm{O}_{2}+\stackrel{2}{\mathrm{C}}_{4} \mathrm{H}_{8}$ & 0 & 0 & 0 & 0 & 0 \\
\hline 7 & $\mathrm{Au} / \mathrm{TiO}_{2}+$ silicalite & $\mathrm{CO}_{2}+\mathrm{O}_{2}+\mathrm{C}_{4} \mathrm{H}_{8}$ & trace & 0 & 0 & not detectable & 0.6 \\
\hline \multicolumn{8}{|c|}{$\begin{array}{l}\text { a } \mathrm{ND}=\text { not determined } \\
\text { b The errors are large for these values, estimated } \pm 20 \% \text { because of small concentrations, handling losses, } \\
\text { and continual decomposition of } \mathrm{H}_{2} \mathrm{O}_{2} \text { during set up for its titration }\end{array}$} \\
\hline
\end{tabular}

Upon dispersion of the catalysts into $\mathrm{H}_{2} \mathrm{O}(\mathrm{t}=0)$, butene 1,2- epoxide was detected in the gas phase. The epoxide amount detected in the gas phase was low initially, as most of it was dissolved in $\mathrm{H}_{2} \mathrm{O}$, but grew with time as the solution concentration increased (Fig. 5). Gas phase butene consumption was low initially as dissolved butene was utilized first (5.62*10-5 moles was dissolved in $50 \mathrm{~mL} \mathrm{H}_{2} \mathrm{O}$ as calculated from ref 18) and the steady state was only reached after $150 \mathrm{~min}$. Thus the total butene consumed was calculated using the steady state value of butene reacted, integrated over the duration of the experiment. The products formed and butene consumed in three separate reactions under identical feed conditions are tabulated as runs 1-3 of Table 1. The variability in the data may arise from the manner 
the feed gas and catalysts were dispersed in the liquid. Runs 4-7 of Table 1 show that when one of the essential components of the reaction, $\mathrm{CO}, \mathrm{C}_{4} \mathrm{H}_{8}$, $\mathrm{Au} / \mathrm{TiO}_{2}$, or TS-1 was omitted, $\mathrm{O}_{\mathrm{xs}}$ was very low or absent and there was no oxygenated hydrocarbon product.

In a separate extended time experiment (Fig. 6), in which the catalysts were placed in $\mathrm{H}_{2} \mathrm{O}$ right at the beginning (thus, the data before 80 min are not steady state data), it was observed that even after 500 min, $\mathrm{CO}$ and $\mathrm{O}_{2}$ conversions appeared to be continually increasing while butene conversion appeared to be steady for a while before it declined with long time on stream. The increases in $\mathrm{CO}$ and $\mathrm{O}_{2}$ conversions were only observed in the binary catalytic system of $\mathrm{Au} / \mathrm{TiO}_{2}$ and $\mathrm{TS}-1$ and were not observed for $\mathrm{Au} / \mathrm{TiO}_{2}$ catalyst alone or $\mathrm{Au} / \mathrm{TiO}_{2}$ and silicalite, which has the same crystal structure as TS-1 but without Ti incorporation, or when butene was omitted from the feed.

\section{Discussion}

The possible role of peroxy in CO oxidation over supported Au catalyst has been suggested by DFT calculation $[19,20]$. We have proposed [21] that this peroxy species may interact with $\mathrm{H}_{2} \mathrm{O}$ to form $\mathrm{H}_{2} \mathrm{O}_{2}$ with the remaining $\mathrm{O}$ atom used in $\mathrm{CO}$ oxidation. Conversely, CO could interact with this peroxy first and the remaining $\mathrm{O}$ proceeds to react with $\mathrm{H}_{2} \mathrm{O}$ to generate $\mathrm{H}_{2} \mathrm{O}_{2}$. We favor the first pathway because we think that the peroxy species is more reactive than the [O] atom deposited as a result of $\mathrm{CO}$ oxidation, and therefore more likely to oxidize $\mathrm{H}_{2} \mathrm{O}$. The resultant $\mathrm{H}_{2} \mathrm{O}_{2}$ could decompose (Eq. 4) or react with $\mathrm{CO}$ to form $\mathrm{CO}_{2}$ ( Eq. 5). As defined, $\mathrm{R}_{\mathrm{Oxs}}$ is the rate of $\mathrm{O}$ consumption beyond what is required for stoichiometric $\mathrm{CO}$ oxidation, and is proposed to be the net rate of $\mathrm{H}_{2} \mathrm{O}_{2}$ generation:

$$
\begin{array}{ll}
\mathrm{H}_{2} \mathrm{O}_{2} & \rightarrow \mathrm{H}_{2} \mathrm{O}+0.5 \mathrm{O}_{2} \\
\mathrm{H}_{2} \mathrm{O}_{2}+\mathrm{CO} & \rightarrow \mathrm{CO}_{2}+\mathrm{H}_{2} \mathrm{O} \mathrm{H}_{2} \mathrm{O}_{2}
\end{array}
$$

The highest $\mathrm{E}_{\text {Oxs }}$, net $\mathrm{H}_{2} \mathrm{O}_{2}$ generated per mole of $\mathrm{CO}$ reacted, was 0.3 upon transfer of $\mathrm{Au} / \mathrm{TiO}_{2}$ into the aqueous phase at room temperature (Fig. 2b). This efficiency rapidly decreased as the solution $\mathrm{H}_{2} \mathrm{O}_{2}$ concentration built up and reactions (4) and (5) became significant. When $\mathrm{E}_{\mathrm{Oxs}}$ reached zero, the formation rate of $\mathrm{H}_{2} \mathrm{O}_{2}$ was balanced by its decomposition/ reduction rates. That this decrease in $\mathrm{E}_{\mathrm{Oxs}}$ was not related to any changes in the catalytic
CO oxidation characteristic could be deduced from the fact that $\mathrm{CO}$ conversion remained constant with time (Fig. 3a). The reactions shown by Eq. 4 and / or Eq. 5 became more rapid at $40^{\circ} \mathrm{C}$ and $\mathrm{E}_{\mathrm{Oxs}}$ was almost zero within uncertainties in a feed of $\mathrm{CO}+\mathrm{O}_{2}$, with or without butene.

On the other hand, when $\mathrm{H}_{2} \mathrm{O}_{2}$ was harnessed by reaction with 1-butene (Eq. 6) in the presence of TS-1, the non-productive reactions of $\mathrm{H}_{2} \mathrm{O}_{2}$ are deterred and the initial $\mathrm{E}_{\mathrm{Oxs}}$ was very high (Fig. 4b); almost approaching unity. This $\mathrm{E}_{\mathrm{Oxs}}$ also decreased with time on stream, but the change was mostly due to increase in $\mathrm{CO}$ conversion (Fig. 4a). In fact, within uncertainties, $\mathrm{R}_{\mathrm{Oxs}}$ remained constant with time on stream (Fig. 4C).

$$
\mathrm{H}_{2} \mathrm{O}_{2}+\mathrm{R}-\mathrm{C}=\mathrm{C} \rightarrow \mathrm{RC}_{2} \mathrm{O}+\mathrm{H}_{2} \mathrm{O}
$$

Butene 1,2-epoxide was detected in the exit gas, formed by reaction of butene with $\mathrm{H}_{2} \mathrm{O}_{2}$ and also in the product solution (Eq. 6), when a mixture of $\mathrm{Au} / \mathrm{TiO}_{2}$ and TS-1 were used as the catalysts. Table 1 shows that in addition to epoxides, 1,2 butane diol was detected in the product solution as the major oxygenated hydrocarbon product. This suggests rapid hydrolysis of the epoxide in an aqueous medium. The sum of hydrogen peroxide, epoxide and diol was smaller than that of the total $\mathrm{O}_{\mathrm{xs}}$, albeit not by an amount that would suggest combustion of butene as a significant pathway as the total combustion of one mole of butene to $\mathrm{CO}_{2}$ and $\mathrm{H}_{2} \mathrm{O}$ would require 12 moles of $\mathrm{O}_{x \mathrm{~s}}$. The fact that the alkene consumed integrated over time was close to $\mathrm{O}_{\mathrm{xs}}$ is also consistent with the fact that combustion of alkene is not a major pathway. Table 1 also shows that the formation of epoxide/diol requires $\mathrm{Au} / \mathrm{TiO}_{2}$ (run \#6) and CO (run \#4). In fact, there were no reactions in those two runs. Isolated $\mathrm{Ti}$ site is also important because when TS-1 was replaced with silicalite (run \#7) only trace amounts of epoxide were detected in the product solution although $\mathrm{CO}$ oxidation was detected.

The increase in $\mathrm{CO}$ and $\mathrm{O}_{2}$ conversions with time (Fig. 4a and Fig. 6) implies the generation of a new catalytic species active for $\mathrm{CO}$ oxidation. The generation of this new species requires the presence of TS-1. It was not formed when the reaction solution contains only $\mathrm{Au} / \mathrm{TiO}$ or when TS-1 was substituted by silicalite (data not shown) in the catalytic system. It is catalytically distinct from $\mathrm{Au} / \mathrm{TiO}_{2}$ as $\mathrm{CO}$ oxidation does not result in the generation of $\mathrm{O}_{x s}$. It is probably formed through 
solubilization of $\mathrm{Ti}$ from $\mathrm{TS}-1$ and/or $\mathrm{Au}$ from $\mathrm{Au} / \mathrm{TiO}_{2}$; a process that depletes the components essential for epoxide formation and thus accounts for the eventual drop in butene conversion for the extended time experiment (Fig. 6).

\section{Conclusion}

A Au/TiO 2 +TS-1 binary catalytic system catalyzes low temperature epoxidation of 1-butene in the aqueous phase. Butene 1,2-epoxide was formed but was extensively hydrolyzed to 1,2-butane diol. During the aqueous phase epoxidation reaction, a new species of highly reactive $\mathrm{CO}$ oxidation catalyst appears to be generated and there is evidence that the new catalyst is made up of both $\mathrm{Au}$ and $\mathrm{Ti}$.

\section{Acknowledgement}

This work was supported by the US Department of Energy, grant DE-FG02-01ER15184. Jian Jiang was supported in part by the China Scholarship Council.

\section{About the authors}

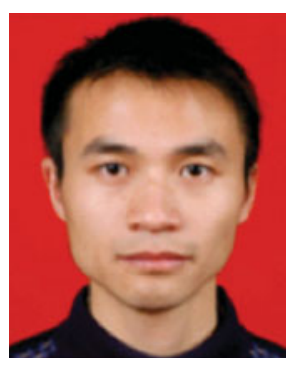

Jian Jiang is a visiting graduate student at Northwestern University. $\mathrm{He}$ is on leave from the College of Chemistry and Chemical Engineering, Lanzhou University where he is getting a Ph.D. degree in the field of catalysis.

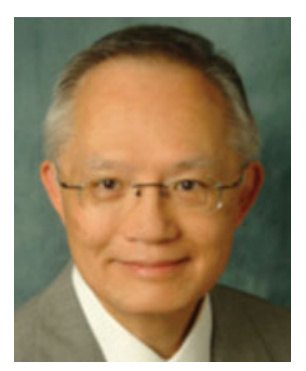

Harold H. Kung is a Professor of Chemical and Biological Engineering at Northwestern University. His interest in catalysis includes solid acid, selective oxidation, and environmental catalysis. He is also developing synthetic methods for novel, nanoscale structures for catalysis.

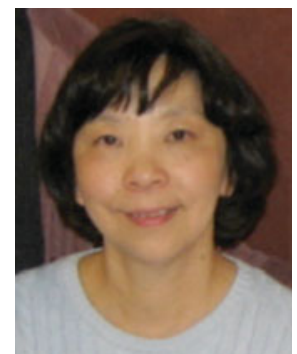

Mayfair C. Kung is a Research Associate Professor in the Chemical and Biological Engineering Department at North Western University. Her research interests include au catalysis, siloxane chemistry and synthesis and catalysis of nanostructured materials.

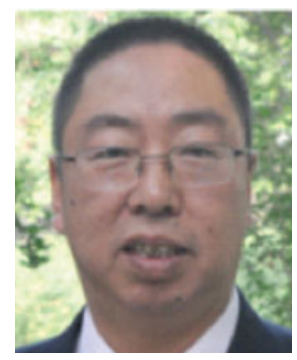

Jiantai Ma is a Professor of College of Chemistry and Chemical Engineering at Lanzhou University. He is interested in industrial catalysts, heterogeneous catalysts for asymmetric hydrogenation and modification of molecular sieve catalysts.

\section{References}

1 M. Haruta, N. Yamada, T. Kobayashi and S. Iijima, J. Catal., 1989, 115, 301

2 Mayfair C. Kung, Robert J. Davis and Harold H. Kung. J. Phys. Chem. C, 2007, 111, 11767

3 J.A. Rodriguez, X. Wang, P. Liu, W. Wen, J.C. Hanson, J. Hrbek, M. Perez, J. Evans, Topics in Cataysis, 44, 2007, 73

4 Graham J. Hutchings, Catal. Today, 2002, 72, 11

5 M.D. Hughes, Y.J. Xu, P. Jenkins, P. McMorn, P. Landon, D.I. Enache, A.F. Carley, G.A. Attard, G.J. Hutchings, F. King, E.H. Stitt, P. Johnston, K. Griffin and C.J. Kiely, Nature (London, U.K.), 2005, 437, 1132

6 L. Prati and F. Porta, Appl. Catal., A, 2005, 291, 199

7 G.J. Hutchings, S. Carrettin, P. Landon, J.K. Edwards, D. Enache, D.W. Knight, Y.J. Xu and A.F. Carley, Topics in Catalysis, 2006, 38, 223

8 R.B. Grant and R.M. Lambert, J. Chem. Soc., Chem. Commun., 1983, 662

9 J. Will Medlin, John R. Monnier and Mark A. Barteau, J. Catal., 2001, 204, 71

10 M. Ojeda and E. Iglesia, Chem. Commun. (Cambridge, U. K.), 2009, 352

11 M. Turner, V.B. Golovko, O.P.H. Vaughan, P. Abdulkin, A. Berenguer-Murcia, M.S. Tikhov, B.F.G. Johnson and R.M. Lambert, Nature (London, U. K.), 2008, 454, 981

12 E.E. Stangland, K.B. Stavens, R.P. Andres and W.N. Delgass, J. Catal., 2000, 191, 332

13 A.K. Sinha, S. Seelan, S. Tsubota, and M. Haruta, Topics in Catalysis, 2004, 29, 95

14 J.J. Bravo-Suarez, K.K. Bando, J. Lu, M. Haruta, T. Fujitani and S.T. Oyama, J. Phys. Chem. C, 2008, 112, 1115 
15 W.C. Ketchie, M. Murayama and R.J. Davis, Topics in Catalysis, 2007, 44, 307

16 M.G. Clerici, Met. Oxide Catal., 2009, 2, 705

17 A. Thangaraj, R. Kumar, S.P. Mirajkar and P. Ratnasamy, J. of Catal., 1991, 130, 1

18 E. Wilhelm, R. Battino, and R. Wilcock, Chem. Rev, 1977, 77, 219

19 L.M. Molina and B. Hammer, Physical Rev. Lett., 2003, 90, 206102

20 R. Coquet, K.L. Howard and David J. Willock, Chem. Soc. Rev., 2008, 37, 2046

21 J. Jiang, S. Oxford, B. Fu, M.C. Kung, H.H. Kung and Jiantai Ma, submitted 